\title{
Uniwersytet bez idei
}

\author{
Artykuł recenzyjny książki Idea uniwersytetu. Reaktywacja \\ pod redakcją Piotra Sztompki i Krzysztofa Matuszka \\ (Kraków 2014: Wyd. Uniwersytetu Jagiellońskiego, ss. 365)
}

\begin{abstract}
STRESZCZENIE. Dorobek Kongresu Kultury Akademickiej, który odbył się w 2014 r. w Krakowie, zawarto w pracy Idea uniwersytetu. Reaktywacja. Jest to krytyka współczesnych trendów w szkolnictwie wyższym i sugeruje restytucję XIX-wiecznego modelu uniwersytetu. W artykule podjęto próbę polemiki z argumentami krytycznymi zarysowanymi $\mathrm{w}$ wystąpieniu inauguracyjnym Piotra Sztompki oraz wyjaśniono, dlaczego powrót do idei Humboldta jest mało realny. Ponadto przedstawiono te elementy strategii instytucjonalnej, które mogłyby się w polskim kontekście sprawdzić, gdyby działania podjęto w krótkiej perspektywie czasowej.
\end{abstract}

SŁOWA KLUCZOWE: uniwersytet, zmiana, kultura akademicka, pracownicy naukowi

\subsection{0 lat tradycji zobowiązuje i obciąża?}

Nic dziwnego, że w roku jubileuszu najstarszego polskiego uniwersytetu ukazała się publikacja, która jest pochwałą czasów minionych. Można było jednak żywić nadzieję, że w przekonujący sposób ukaże się tam, jak tradycyjna idea uniwersytetu wchodzi w interakcję ze zmieniającymi się warunkami socjoekonomicznymi, w jaki sposób podlega redefinicji i zastępowana jest przez inne idee. Ze względu na obecność wielu znanych autorów i autorek ze świata humanistyki można było oczekiwać oryginalnych lub chociaż zastanawiających wątków, które pozwolą stworzyć nową (mniej emocjonalną i ideologiczną, bardziej rzeczową, analityczną, usystematyzowaną) perspektywę oglądu współczesnych problemów uczelni w Polsce. Zanim przejdę do krytycznej oceny i ewaluacji Idei uniwersytetu. Reaktywacji, powiem kilka słów o samej strukturze i zawartości tej publikacji. 
Książka ta stanowi pokłosie Kongresu Kultury Akademickiej, który był częścią obchodów jubileuszu 650-lecia Uniwersytetu Jagiellońskiego. Kongres odbył się 20-22 marca 2014 r. w Krakowie i zgromadził kilkuset uczestników i uczestniczek $^{1}$. W tomie zamieszczono 36 tekstów z tego spotkania, kierując się, jak się wydaje, dwoma kryteriami: prestiżowym (aby uwzględnić głosy ważnych i zasłużonych uczonych, zwłaszcza dla polskiej humanistyki) i merytorycznym (by w miarę możliwości oddać w tomie treść wszystkich paneli i sympozjów). Pomijając wstępy redaktorów, w książce wydzielono następujące rozdziały: Misja uniwersytetu dzisiaj (rozdz. 1), Uniwersytet a przestrzeń publiczna (rozdz. 2), Humanistyka $w$ uniwersytecie (rozdz. 3), Dylematy organizacji uniwersytetu (rozdz. 4), Uniwersytet $w$ czasach rewolucji cyfrowej (rozdz. 5). Wydawać by się mogło, że pierwsze trzy części będą dotyczyć wspomnianej idei uniwersytetu, a pozostałe dwie - zawierać instrukcje dotyczące jej „reaktywacji”, to znaczy przezwyciężenia problemów trapiących współczesne uczelnie. Książka nie jest jednak pracą stricte naukową, a raczej zbiorem refleksji o kondycji współczesnego uniwersytetu.

Mimo „rewolucji cyfrowej”, której uczestnicy Kongresu wydawali się być świadomi (por. rozdz. 5), a więc m.in. tego, że wiele debat tego rodzaju przeniosło się do Internetu, nadal jest ważne, żeby o kondycji „akademii” dyskutować w toku spotkań środowiskowych. Dostojeństwo uniwersytetu materializujące się w jego wiekowych murach i możliwość bezpośredniej polemiki z najznamienitszymi jej reprezentantami powinny pozytywnie wpływać na dogłębność i rozważność (ale także rzetelność i empiryczne zakotwiczenie) prezentowanych tez. Tak by się mogło wydawać. Na przeszkodzie stanęły jednak dwie kwestie. Cel konferencji był zideologizowany, nastawiony jednoznacznie na krytykę współczesności i wprowadzonych reform (z wielu względów niedoskonałych, ale jednak koniecznych):

[...] kongres, pomyślany jako potrzeba przeciwstawienia się tendencjom fałszywej modernizacji, w kierunku której zmierzają obecnie polskie szkoły wyższe, a jednocześnie jako remedium mające na celu obronę etosu środowiska akademickiego (Matuszczek 2014: 10).

W tak zdefiniowanym celu zawierają się dwie tezy o charakterze wartościującym: (1) że wszelkie współczesne próby reform były szkodliwe i (2) że jedynie środowisko sceptyczne wobec zmian charakteryzuje się środowiskowym etosem. Reszta, ponieważ hołduje fałszywym wartościom, go nie posiada. Drugi z redaktorów dodał, że „teren uniwersytetu zaatakowała niczym wirus, diametralnie przeciwna jego naturze [tj. uniwersytetu - M.S.] kultura korporacyjna, której właściwe miejsce to firmy, przedsiębiorstwa, banki, urzędy administracyjne" (Sztompka 2014: 19), co należy uznać za plastyczną metaforę, ale niezbyt ugruntowane twierdzenie naukowe. Uniwersytety należą do sfery publicznej, która w wielu obszarach - z korzyścią dla petentów i władz - wprowadziła standardy korporacyjne

\footnotetext{
${ }^{1}$ Strona Kongresu Kultury Akademickiej: http://kongresakademicki.pl/.
} 
(Popławski, Markowski i Forkiewicz 2013). Z zagranicy także docierają do nas liczne pozytywne przykłady funkcjonowania tzw. uniwersytetu przedsiębiorczego (OECD 2008).

Zaledwie 8 autorów tekstów w recenzowanym tomie w nieśmiały sposób sugerowało, że być może tak postawiony cel Kongresu nie jest do końca trafny i adekwatny wobec istoty problemów trapiących szkolnictwo wyższe, które na pewno istnieją i trzeba nad nimi dyskutować. Poza tym o problemach polskiej dydaktyki i nauki (bo większość artykułów zdecydowanie wykraczała poza same uniwersytety, a dotyczyła raczej kwestii systemowych) wypowiadali się nie badacze szkolnictwa wyższego, nie fachowcy, doradcy czy architekci kierunków polityki naukowej, ale zwykli jej adresaci. Z 35 autorów 7 można uznać za ekspertów ze względu na ich zainteresowania badawcze lub doświadczenie w kształtowaniu polityki wobec szkolnictwa wyższego na szczeblu centralnym. Pozostali autorzy to zasłużeni akademicy (często także z rozległym doświadczeniem organizacyjnym).

Niestety większość umieszczonych w tomie tekstów to listy zawierające pretensje do władz i środowiska naukowego (nie oceniam, na ile słuszne), oparte przede wszystkim na własnych (nawet jeżeli bardzo bogatych, to jednak subiektywnych) doświadczeniach. Wiele $\mathrm{z}$ nich to $\mathrm{w}$ zasadzie zbiór anegdot z życia profesorów, gdzie diagnoza kondycji uniwersytetu przedstawia się następująco: „przeszłość piękna, wzniosła, pozbawiona problemów, współczesność - zła, pozbawiona sensu, zmierzająca do katastrofy". Zanadto przypomina to proces idealizacji młodości (nawet jeżeli przypadła ona na trudne czasy wojny lub stalinizmu), żeby nie podchodzić do takiego zjawiska sceptycznie (por. Labouvie-Vief i Blanchard-Fields 1982; Wylęgała 2014: 392). Nawet jeżeli przeszłość rzeczywiście była lepsza czy wznioślejsza, fakty są takie, że borykamy się dziś ze współczesnością, którą trzeba w jakiś sposób oswoić, a najlepiej wykorzystać wszystkie jej dobrodziejstwa.

Niektóre powtarzające się argumenty funkcjonują jako „klisze”. Jednym z przykładów jest twierdzenie, że Kopernik, Skłodowska-Curie lub Einstein nigdy nie dostaliby grantu w Narodowym Centrum Nauki. Obok tego rodzaju tez, które trudno uznać za naukowe - wszak to ocena przeszłości z wykorzystaniem współczesnych narzędzi (radykalny prezentyzm) - zabrakło rzetelnych analiz rzeczywistego funkcjonowania systemu grantowego w Polsce. Artykuł prof. Andrzeja Jajszczyka (2014: 279-292), który był jednocześnie dyrektorem tej niezbyt popularnej w środowisku instytucji, niestety tego problemu nie neutralizuje. Tekst zawiera informacje na temat funkcjonowania NCN, ale nie ma w nim zbyt wielu szczegółowych danych ilościowych, a zwłaszcza tak potrzebnych jakościowych, żeby móc odnieść się do tego, czy faktycznie jest jakaś prawidłowość w finansowaniu jednych tematów badawczych i pozbawianiu środków finansowych innych. W tym obszarze, jak i w wielu innych, Kongres powielił stereotypy, zamiast je podważyć.

W raporcie dotyczącym zarządzania uniwersytetami autorstwa Dominika Antonowicza i Bena Jongbloeda zwrócono uwagę na znaczny konserwatyzm środowiska 
pracowników naukowych w Polsce, niechęć wobec zmian, a zwłaszcza redefinicji stosunków władzy na uczelniach (Antonowicz i Jongbloed 2015: 90-95). W ramach tego projektu prowadzono wywiady z głównymi interesariuszami środowiskowy$\mathrm{mi}$, z rozległym doświadczeniem organizacyjnym i rozwiniętymi kontaktami wśród pracowników naukowych. Choć zdawali sobie oni sprawę, że ewentualne zmiany miałyby służyć lepszemu dopasowaniu się do wymogów rzeczywistości, negatywnie ocenili możliwość ich wprowadzenia. Nie określono w tym studium precyzyjnie skali tego konserwatyzmu, ale autorzy zwrócili uwagę w rekomendacjach, że decydenci nie mają co czekać na aprobatę środowiska naukowego, którego dotyczą zmiany w polityce naukowej, ponieważ szanse na jej uzyskanie są znikome, jeżeli nie żadne (Antonowicz i Jongbloed 2015: 99-102). Pracownicy naukowi nie chcą elastycznych i społecznie odpowiedzialnych uczelni, z radami powierniczymi dopuszczającymi interesariuszy zewnętrznych, nie chcą też, by rola ciał kolegialnych, składających się z pracowników naukowych, była w jakiś sposób ograniczana. Nie widzą plusów w hierarchizowaniu struktury podejmowania decyzji administracyjnych. Przekazanie pieczy nad uniwersytetem w ręce profesjonalistów (menedżerów), co może być opłacalne i co potwierdzają przykłady z innych krajów europejskich (autorzy przeanalizowali przypadek austriacki, holenderski i portugalski), kojarzy im się z zamachem na wolność i autonomię uniwersytetu. Wydźwięk recenzowanego tomu, poprzez totalną krytykę współczesnego uniwersytetu i prób jego modernizacji (przeprowadzony z wielu różnych punktów widzenia), w pełni potwierdza diagnozę autorów wspomnianego raportu. Niechęć środowiska nie odnosi się zresztą jedynie do wprowadzania zmian w zarządzaniu, ale także do dopasowywania kształcenia do wymogów procesu bolońskiego (np. Modzelewski 2014: 220), ewolucji relacji między głównymi aktorami w dydaktyce (Woleński 2014: 101-112; Drozdowski i Flis 2014: 113-123), Krajowych Ramach Kwalifikacji (np. Tadeusiewicz i Ligęza 2014: 237-252), wzrostu roli rankingów indywidualnych i uczelnianych (np. Leja 2014: 197-198), a nawet kwestii języka angielskiego jako uniwersalnego sposobu komunikowania wyników badań naukowych (Kula 2014: 82).

\section{Piękna młodość, szpetna dojrzałość. 0 głównych problemach współczesnego uniwersytetu}

Referat Piotra Sztompki zarysował ramy dyskusji na Kongresie. Większość autorów tekstów odnosiła się do nich, dlatego też warto poświęcić im chwilę uwagi. Zdaniem Sztompki we współczesnym uniwersytecie dochodzi do zderzenia dwóch kultur: akademickiej (tradycyjnej, zakorzenionej jeszcze w średniowieczu) i korporacyjnej, której zbyt pochopna akceptacja doprowadziła do kryzysu uniwersytetu (Sztompka 2014: 19). Można się z pewnością zgodzić, że mamy do czynienia z konfliktem w obszarze kultury, przede wszystkim jednak jest to konflikt uobecniający 
się w percepcji osób zanurzonych w jednej z tych kultur. Logika działania elitarnej, odizolowanej od świata wspólnoty naukowców jest inna niż biurokratycznie zorganizowanej machiny, z rozbudowanym aparatem profesjonalnym i administracyjnym. Uwarunkowania zmieniają się szybciej niż kultura w jakiejkolwiek organizacji (North 1990). Trudno jednak nie przyznać, że model korporacyjny uczelni jest odpowiedzialny za wszelkie patologie w szkolnictwie wyższym. Wprowadzenie większej transparentności, rozliczalności, autonomii i odpowiedzialności - bo z tym też wiąże się koncepcja uniwersytetu przedsiębiorczego (Clark 1998) - raczej nie przysporzyły obciążeń akademii, wręcz przeciwnie: pomogły jej działać i konkurować na arenie globalnej. Kultura korporacyjna nie jest wolna od wad (por. Fryzeł 2005: 137-142; Zając 2012: 71-87), ale nie można zapominać, że jej cele miały być remedium na część problemów, których doświadczała uczelnia. Tradycyjne uniwersytety były „wieżami z kości słoniowej”, ale bynajmniej nie były nieskalane patologiami (por. Goćkowski i Kisiel 1994; Portal Niezależnego Forum Akademickiego; Wroński 2010).

Realnie patrząc na problemy nauki polskiej, kwestia kultury korporacyjnej na uczelniach jest w pewnym sensie tematem zastępczym. Być może ważniejszą sprawą jest to, że o funkcjonowaniu nauki (a także dydaktyki) decyduje niewielki odsetek profesorów (kwestia demokratyzacji szkolnictwa wyższego). Nie bez znaczenia jest też to, że środowisko akademickie nigdy nie sformułowało spójnej alternatywy dla kultury korporacyjnej, jest więc poniekąd współodpowiedzialne za stan rzeczy.

Sztompka negatywnie odnosi się do faktu, że relacje mistrz - uczeń zastępuje personel (menedżerowie i pracownicy) oraz klienci (studenci). Trudno się zgodzić z takim ujęciem sprawy, przynajmniej w tak skrajnej wersji. Kultura korporacyjna modyfikuje stosunki na uniwersytecie, obudowuje je w ramy, precyzuje obowiązki i przywileje, co przeciwdziała nadużywaniu władzy wobec mniej uprzywilejowanych (Wieczorek 2003). Praca naukowa jest twórcza i często odbywa się w małych zespołach, wytwarzając wspólnotowe relacje (mimo współwystępowania oficjalnej kultury korporacyjnej). Także uczciwie prowadzony tutoring wobec własnych seminarzystów pozwala na stworzenie nowoczesnej relacji mistrz - uczeń (Cichorzewska 2014). Oczywiste jest to, że nie będzie ona przypominała relacji sprzed wieku, ale przyszło nam funkcjonować dziś w zupełnie innych warunkach. Szkolnictwo wyższe przeszło etap umasowienia czy wręcz upowszechnienia dostępu, programy studiów zostały wystandaryzowane i dziś trzeba umieć odnaleźć się w tych nowych okolicznościach.

Przeciw kulturze korporacyjnej na uniwersytetach zdaniem Sztompki przemawia także to, że ruguje ona prawdziwe więzi społeczne, a zastępuje je interesami, które są obudowane w regulaminy i statuty. Jest to nieco dyskusyjne. Czy dlatego, że w jakimkolwiek sporcie są reguły gry, to staje się on przez to mniej emocjonalny, a uczestnicy mniej oddani rozgrywce? Czy dlatego, że małżeństwo sankcjonuje się prawem, jest ono mniej prawdziwą więzią niż wolny związek? Czy jeżeli muzyk 
lub malarz, zamiast pracować na ulicy, dostaje umowę o pracę i zaczyna poświęcać swój czas konkretnej instytucji kulturalnej, to jego talent traci, a zaangażowanie słabnie? Podmiot włączony w sformalizowane otoczenie po prostu się zmienia, ponieważ zaczyna funkcjonować w obrębie ustalonych ram. Reguły postępowania, określające minimalny poziom zaangażowania, nie hamują tych najbardziej ambitnych, ale mobilizują tych mniej pracowitych. Duża organizacja, jaką jest uczelnia, wymaga mechanizmów kontroli zewnętrznej, obok oceny środowiskowej. Moralnym obowiązkiem naukowca jest prowadzenie rzetelnych badań i publikowanie ich wyników (por. Karwat 2005; Kodeks etyki pracownika naukowego 2012). Nie wykluczają one współpracy, solidarności i odpowiedzialności za siebie nawzajem. Praktyka funkcjonowania w wielu dyscyplinach naukowych pokazuje, że jest to zajęcie wybitnie zespołowe. Dzięki pracy w grupie można osiągnąć lepsze wyniki, a na pewno będzie to można zrobić w krótszym czasie. Regulaminy i przepisy dotyczące pracy naukowej i dydaktycznej mają chronić także naukowców na niższych szczeblach kariery przed (nie zawsze słusznymi) roszczeniami przełożonych. Czynią też cały system mniej hermetycznym i przejrzystym. Jeżeli znane są zasady gry, może grać każdy, kto jest w stanie zainwestować swoje talenty i czas.

„Motywacje instrumentalne, czyli zarobek, są we wspólnocie uniwersyteckiej wtórne” (Sztompka 2014: 21). Tu nic się w zasadzie nie zmieniło i chyba się nie zmieni (por. Heller 2009: 21). Mimo wprowadzania elementów kultury korporacyjnej praca naukowa zawsze będzie w większym stopniu pasją niż posadą. Żadna racjonalnie kalkulująca jednostka nie wybierze takiej drogi życiowej, jeżeli nie widzi w tym wartości samej w sobie. Żadne pieniądze nie są w stanie wynagrodzić pracy w dzień i w nocy, w dni powszednie i święta i niepokoju intelektualnego, który towarzyszy każdemu badaczowi przez większość czasu. Praca naukowa nie jest zajęciem, które kończy się wraz z opuszczeniem budynku uczelni.

Sztompka optymistycznie sądzi, że uniwersytet to instytucja samoregulująca się i nie potrzebuje formalnej dyscypliny i sankcji, a wystarczy jej zinternalizowany mechanizm dumy i wstydu (Sztompka 2014: 21). Zawsze, jak to w każdym środowisku, także i tu dochodziło do nieuczciwości (por. Goćkowski i Kisiel 1994; Wieczorek 2010; Buranen i Ray 1999). Przeświadczenie, że środowisko naukowe powinno hołdować najwyższym etycznym standardom, jest bardzo ważne, ale od samego powtarzania go standardy te nie ulegną poprawie. Na rynku potrzebne są przepisy, żeby eliminować nieuczciwą konkurencję, więc i tu potrzebne są regulacje, które powinny określać cechy solidnej pracy naukowej i obligować do jej wykonywania wszystkich zatrudnionych z publicznych środków badaczy. Odpowiedzialność przed społeczeństwem (a nie hermetyczna, środowiskowa) powinna być tą, które kieruje badaczem. Choć trzeba też tu dążyć do „złotego środka”. Brak zaufania władz, formułowanie szczegółowych regulacji i narzucanie ich z zewnątrz jest istotnym (jeśli nie najważniejszym współcześnie) problemem uniwersytetów (Pacholski 2015; Antonowicz i Jongbloed 2015: 100-103). 
Sztompka powtórzył za Znanieckim, że „uczony musi być trzymany na bardzo długiej smyczy" [ale jednak smyczy! - M.S.] (2014: 22; Znaniecki 1940). Praca naukowa wymaga wolności, swobody, tolerancji dla indywidualnego rytmu pracy, otwarcia się na to, co nieprzewidywalne i nieznane, na rolę przypadku i szczęścia (serendipity), ale musi też dawać jakieś efekty, ponieważ jest opłacana przede wszystkim ze środków publicznych (a tu nawet brak wyniku może być jakąś odpowiedzią, pokazuje bowiem, że obrana ścieżka okazała się ślepa, i oszczędza to trudu innym naukowcom). Wszyscy, którzy zajmują się nauką, mając status „prywatnych uczonych”, mogą mieć nieograniczoną swobodę w zakresie wyboru tematu badań i tempa prac (poza oczywiście ograniczeniami wynikającymi ze współczesnego stanu wiedzy i uniwersalnej etyki). Pozostali, którzy korzystają z cudzych funduszy (czy to publicznych, czy prywatnych), muszą się liczyć z oczekiwaniami suwerena i nie chodzi tu o manipulowanie wynikiem (a chyba tego obawia się większość sceptyków), tylko o kierunek i obowiązek rzetelnej pracy. Być może schematyczne systemy grantowe preferują bardziej uporządkowane i przewidywalne projekty (co jednak, zanim podniesie się alarm, należałoby poddać szczegółowej analizie jakościowej). Nie jest to jednak powód, żeby potępiać w całości celowy system finansowania badań, a raczej dążyć do jego udoskonalenia. Lepszego systemu, póki co, nie wymyślono. Poza tym nie wszystko, co budzi ciekawość, jest warte badania, z perspektywy bardziej uniwersalnych celów (por. Szlachta 2013: 44-52).

Wszyscy uczeni są zobowiązani do dążenia do wybitności. Jednocześnie wiadomo, że nie wszyscy tę wybitność osiągną. Jest ona zarezerwowana dla znikomego odsetka ludzi na Ziemi, co potwierdza rozkład normalny większości cech w społeczeństwie. Skrajne wartości mierzonej zmiennej charakteryzują niewielu. Zgodnie z analizami Marka Kwieka 10\% uczonych w Polsce (i w 10 innych badanych krajach) tworzy 50\% dorobku naukowego (Kwiek 2015a). Czy jednak byłoby czymś złym wymagać od wszystkich jakiegoś rozsądnego pułapu produktywności, tj. prowadzenia badań i publikowania ich wyników ze względu na fakt ich opłacania z publicznych środków? Problem, jak zwykle zresztą, tkwi w szczegółach, ponieważ pracownicy naukowi generalnie nie sprzeciwiają się temu postulatowi (Karwat 2005). Jaki jednak miałby być ten rozsądny pułap? Skoro nie jesteśmy w stanie wszyscy osiągnąć wybitności, starajmy się być jak najlepszymi rzemieślnikami. Rzetelność jest bardzo ważna w pracy naukowej. Geniusz, bez dyscypliny i rzetelności, jest niewiele wart (por. Coyle 2012).

Z problemem osiągnięć łączy się kwestia ich porównywania. Sztompka krytykuje system punktowy, preferując ocenę środowiskową. Wydaje się, że za większością ekwiwalentów punktowych stoi właśnie ocena środowiskowa (peer review), czy to w procesie akredytacji instytucjonalnej (wszak PKA ma swoich ekspertów, którzy reprezentują środowisko), czy w procesie publikowania artykułów (zanim tekst się ukaże, przekazywany jest do recenzji specjalistom z dyscypliny, którzy najczęściej wyrażają swoją opinię w sposób opisowy). Zatem nie jest tak, że ba- 
dacze zbierają punkty, które nic nie znaczą. Są one jakimś sposobem oceniania produktywności badaczy. Na pewno niedoskonałym i o poprawieniu systemu należy dyskutować (Kulczycki 2015; Zabel i in. 2014; Żylicz 2006). Kontrowersyjna jest chociażby liczba punktów przyznawana za opublikowane monografie - to mało znacząca wartość, co powoduje, że bardziej racjonalną („opłacalną”) strategią jest przygotowanie i złożenie artykułu do wysoko punktowanego czasopisma z listy filadelfijskiej. Realnym problemem są tu więc raczej strategie adaptacyjne środowiska. Jeżeli etos środowiskowy jest tylko zbiorem czczych deklaracji, tj. nie jest w nim najważniejsza zwykła uczciwość, dążenie do prawdy i najwyższa jakość prowadzonych badań, a właśnie zbieranie owych punktów, to tu raczej mamy sedno problemu. Jeżeli środowisko nie widzi nic złego w wielokrotnym publikowaniu niemal identycznych tekstów lub posyłaniu ich do zaprzyjaźnionych redakcji w nadziei na łagodniejszą recenzję, to jest to z pewnością oznaka jego głębokiej zapaści. Jest w tym dwuznaczność, ponieważ środowisko naukowe pretenduje do roli elity etycznej - chce pouczać innych, jak powinno się postępować, nawet jeżeli nie są to najłatwiejsze wybory, a samo często obiera drogę „na skróty”.

Nauka nie jest demokratyczna, a elitarna (Sztompka 2014: 24-25; Heller 2014: 33-36) i mechanizm selekcji i zarządzania we współczesnych uniwersytetach istotnie działa na zasadach autonomicznych, ale nie działa bez zarzutu. Są sytuacje personalnych niechęci, powiązań rodzinnych i innych pozamerytorycznych przesłanek, które zmieniają życie niektórych - skądinąd zdolnych naukowców - w piekło. Tajemnicą poliszynela jest, że blokowane są awanse, a na prestiżowych stanowiskach znajdują się osoby, które swoją aktywność naukową zakończyły dawno temu. Old-boys network mocno się trzyma, choć jest niewidoczna dla obserwatora z zewnątrz (Martino 1992: 49-50)². Ze względu na złożoność i rozrost obecnego systemu każdy współczesny mistrz powinien starać się być możliwie dobrym (sprawnym) kierownikiem i menedżerem swojego zespołu. Jego rola jako mentora musi zejść na drugi plan. Może dochodzić w tego rodzaju sytuacjach do trudnych dylematów roli, ale w obecnych warunkach wydaje się to nieuniknione.

Czy uniwersytet ma dostarczać studentom gotowych zestawów umiejętności zawodowych, dopasowanych do konkretnych stanowisk pracy? Wydaje się, że zależy to od uniwersytetu i jego misji oraz oczekiwań samych studentów - czy wolą konkretny zestaw umiejętności, czy wiedzę i kompetencje, które dają możliwości wykonywania wielu różnych zawodów. Myślę, że kształcenie akademickie (to elitarne) powinno być możliwie szerokie, wszak absolwenci najbardziej prestiżowych uniwersytetów są potencjalnymi członkami klasy kreatywnej, zwłaszcza superkreatywnego rdzenia i bohemy, jak je określił Richard Florida (2010: 83-84). W warunkach masowego szkolnictwa kompetencje i oczekiwania studentów są zróżnicowane i taka też powinna być - jak się wydaje - oferta uniwersytetów.

${ }^{2}$ Swoją drogą mógłby to być fascynujący (ale i bardzo wymagający) temat badań. 
„Goniąc uciekającą »nowoczesność « krajów bardziej rozwiniętych, zostajemy ciągle na peronie, spóźnieni o kilka lat” (Sztompka 2014: 28). Zapóźnienia te powstały ze względu na skomplikowane losy naszego kraju, ale pozostawanie w bezruchu i niewprowadzanie żadnych zmian pewnie tylko to zapóźnienie zwiększy. Próby reform nauki w Polsce, $\mathrm{w}$ wielu przypadkach niedoskonałe (bo pozbawione radykalności i kompleksowości), dają jednak szansę, żeby to zapóźnienie chociaż się nie zwiększało, a przy odrobinie szczęścia możemy mieć szansę nieco ten dystans odrobić (por. Intencje i skutki... 2012: 3-36). Korzystnie byłoby panować nad systemem szkolnictwa wyższego w Polsce, bo to nie jest kilka odciętych od świata „wież z kości słoniowej”, ale rozbudowana i niezwykle kosztochłonna sieć instytucjonalna, która jest opłacana solidarnie przez wszystkich podatników. Etap cięcia kosztów i profesjonalizacji zarządzania przeszła większość liczących się systemów w Europie (por. Amaral, Kogan i Gornitzka 2007; Antonowicz i Jongbloed 2015; Kwiek 2015b; 2015c). Obecnie w elitarności i jakości oferty szuka się przewagi konkurencyjnej uczelni, ale wszystkie one przeszły najpierw przez ten bolesny i trudny etap restrukturyzacji. Wprowadzenie transparentności i większej odpowiedzialności za generowane koszty (a więc za podejmowane działania badawcze) może pomóc w uzyskaniu społecznego poparcia na większe niż dotychczas finansowanie - zatem w dłuższej perspektywie może się opłacić.

Obecny system nie jest wolny od problemów, ale żaden model uniwersytetu nie był idealny, jak mu się bliżej przyjrzeć. Za „równością” nauki w Polsce Ludowej kryła się presja ideologiczna, naciski partyjne i inwigilacja. Zresztą równość ta była bardziej deklaratywna niż faktyczna. Nie sądzę, żeby ktokolwiek za tym tęsknił. W okresie pożogi wojennej i bezpośrednio po też nie było łatwo zajmować się nauką. Dziewiętnastowieczny uniwersytet w służbie administracji państw zaborczych, który miał kształcić jedynie posłusznych urzędników też nie był wolny od wad. Z przykładów wynika, że czasem tylko idealizujemy to, co było, ponieważ kojarzy się nam z własną młodością, okresem idealizmu i przeświadczeniem, że wszystko było wtedy możliwe. Im więcej czasu upływa od konkretnych wydarzeń, tym częściej ich historia jest modyfikowana, opowiadana na nowo, idealizowana lub całkowicie przeinaczana.

\section{Reaktywacja uniwersytetu von Humboldta - po co?}

Większość tekstów zaprezentowanych w recenzowanym tomie sugerowała jakąś chęć powrotu czy restytucji idei z przeszłości, które odnosiły się do tradycyjnej akademii, do elitarnej wspólnoty akademików i działającej na ich rzecz instytucji. Takie projekty wydają się jednak utopijne i sentymentalne, ze względu na współczesne cechy systemu szkolnictwa wyższego. Wyjątkiem w tym zakresie był wyrazisty tekst Mirosławy Marody (2014: 135-140), która powiedziała wprost, że to 
w procesach, które przeorganizowały układ zależności tworzący XIX-wieczny uniwersytet, należy szukać przyczyn „kryzysu współczesnego uniwersytetu”. Problem tkwi więc w otoczeniu socjoekonomicznym, a nie w organizacji samej uczelni i jej kulturze organizacyjnej. Uniwersytety nie funkcjonują dziś w izolacji, ale są poddawane procesom globalizacji. Prowadzone przez naukowców badania powinny nadążać za nauką światową, a kształcenie (w jakiś sposób - być może przez edukację zawodową) za potrzebami gospodarki³ . Bez tego nie da się stworzyć społecznego poparcia dla nauki i kształcenia. Marek Kwiek w jednym ze swoich tekstów pisał o sprzyjających dyskursach, które miałby skłonić opinię społeczną i decydentów do utrzymania wysokiej pozycji szkolnictwa wyższego (Kwiek 2015b: 6). Uniwersytety, podobnie jak inne instytucje sektora publicznego, są silnie zależne od kontekstu społecznego i ekonomicznego, natomiast współczesne państwo opiekuńcze nie jest w stanie sprostać wszystkim potrzebom i oczekiwaniom. Najbardziej palącą kwestią jest dziś problem zabezpieczeń społecznych i służby zdrowia, co spycha zagadnienia edukacyjne na margines. Uniwersytet nie jest też już miejscem jedynie wspierania dziedzictwa narodowego i pamięci zbiorowej. Dlatego trzeba poszukać nowej idei uniwersytetu i najlepiej byłoby, gdyby uczeni mieli w tym swój udział (Kwiek 2015b: 17). Stąd, mimo obiektywnych trudności na drodze do reaktywowania idei uniwersytetu von Humboldta i wielu bardzo krytycznych stanowisk wygłaszanych podczas zjazdu, samą koncepcję organizacji Kongresu Kultury Akademickiej uważam za bardzo cenną. Być może w efekcie późniejszego namysłu, kolejnych komentarzy i lektur wyłoni się jakaś nowa koncepcja, która „skolonizuje” przychylne dyskursy.

Zależność od publicznych środków jest charakterystyczną cechą nie tylko polskich uniwersytetów, ale uczelni europejskich w ogóle, zwłaszcza w obszarze badań naukowych (por. Kwiek 2010; Eurostat 2015). Mówienie o całkowitej prywatyzacji systemu (dydaktyki i badań) jest postulatem tak samo nierealnym, jak powrót do modelu uniwersytetu z czasów von Humboldta. Nie jest to na dziś „do wyobrażenia" i nie jest nawet poddawane pod dyskusję. Jednak dywersyfikowanie źródeł przychodów może uczelniom przynieść korzyści. Ten cel da się osiągnąć, wykorzystując doświadczenia Zachodu, a więc próbować dążyć do większej samodzielności uczelni w pozyskiwaniu środków na własną działalność. W obszarze badań pomocne może być m.in.: wspieranie przedsiębiorczości akademickiej, tworzenie partnerstw z przemysłem i funkcjonowanie w świecie medialnym. Są to kwestie wieloaspektowe i same działania uczelni oczywiście wszystkich spraw nie rozwiążą, ale mogą pomóc.

${ }^{3} \mathrm{~W}$ jednej z rozmów przeprowadzonych z ważną postacią dla polskiej polityki naukowej przedstawiono mi odmienny pogląd na tę sprawę, który do dziś uważam za inspirujący. Nie należy myśleć o nadmiernym dopasowywaniu się do potrzeb gospodarki. Trzeba młodzież kształcić tak, żeby miała potencjał do samodzielnego kształtowania rynku pracy i tej gospodarki. Nie chcemy przecież produkować jedynie wyrobników. Chcemy klasy kreatywnej, która będzie przekształcać polską rzeczywistość. 
Po pierwsze, uczelnia może tworzyć instytucjonalne instrumenty wsparcia i upowszechniać ideę przedsiębiorczości akademickiej, co się już poniekąd dzieje. Według danych PARP z 2009 r. w spółki typu spin-off i spin-out było zaangażowane zaledwie 9\% środowiska naukowego (Banerski i in. 2009: 68). Wydaje się, że jest tu jeszcze przestrzeń dla zintensyfikowania działań. Uczelnie mogą premiować obiecujące projekty badawcze i tworzyć wsparcie instytucjonalne dla przedsiębiorstw w postaci inkubatorów. Wymaga to cierpliwości i czasu, ale powinno przynieść efekty. Większość inicjatyw tego rodzaju jest w Polsce relatywnie nowa.

Po drugie, uczelnia jest stroną i beneficjentem tego rodzaju relacji. Praktyczne zastosowania i wdrożenia są ostatnim etapem wielu prac naukowych. Problem w tym, że jak pokazują doświadczenia krajów zachodnich „zwiększanie dopływu funduszy z drugiego źródła [tj. sektora prywatnego - M.S.] bez zwiększania ich dopływu ze źródeł państwowych nie jest możliwe w systemach niedofinansowanych. Lepsze relacje uniwersytety-przedsiębiorstwa wymagają znacznego nakładu finansowego państwa, a metody zachęcania partnerstw uczelni z gospodarką są powszechnie znane w Europie" (Kwiek 2010: 30). Znów więc dochodzimy do fundamentalnego problemu zaufania i potrzeby przełamywania stereotypów.

Po trzecie, medialny PR szkolnictwa i nauki polskiej wydaje się koniecznością, ponieważ popularyzuje wiedzę o osiągnięciach naukowych, promuje je i ich autorów oraz uzasadnia sposób wydatkowania środków publicznych, a także kształtuje zainteresowania odbiorców (Pruchnicka 2012: 166-169). Przez pracowników naukowych jest to postrzegane jako konieczność, do której podchodzą z dystansem, ale nie z niechęcią (Kiełb-Starczewska 2012).

Piotr Sztompka zaproponował wspólistnienie wyizolowanych dwóch logik działania (wspólnotowej i menedżerskiej). Mogłoby się to udać, jeśli by uwzględniono mediatorów, którzy będą rozumieli logikę obu porządków i potrafili pogodzić sprzeczne interesy. Nie jest możliwe scedowanie na administrację zadania uzupełniania aparatury w laboratoriach, książek w bibliotekach czy pisania wniosków grantowych. Samą techniczną czynność być może da się delegować, jednak w każdym wypadku nadal będzie potrzebny nadzór merytoryczny. Bez jakiegoś powiązania tych dwóch porządków będzie to bardzo trudne. Określenie wymogów dotyczących roli badacza i dydaktyka oraz zakresu jego podległości wobec osób ulokowanych wyżej w strukturze wydaje się funkcjonalne i zapobiegające nadużyciom. Konieczność zachowania transparentności i rozliczalności to z kolei współczesny fundament jakiejkolwiek autonomii organizacyjnej. Być może więc te dwie - na pozór sprzeczne logiki - są współbieżne?

Głównym problemem uczelni jest brak wizji czy pomysłu na własne działanie, na własne miejsce w systemie szkolnictwa i w regionie, w którym uczelnie te funkcjonują. Pomimo zapowiedzi zawartych w tytule, również Idea uniwersytetu. Reaktywacja pozostawia nas na tym polu bez odpowiedzi. 


\section{Co w zamian?}

Po pierwsze, współczesny uniwersytet może szukać szans w eksponowaniu swego dostojeństwa, tradycji. Instytucje długiego trwania są mocniej zakorzenione w społeczeństwie i cieszą się większym zaufaniem społecznym, przez co są bardziej stabilne (choć być może nieco konserwatywne i niechętne zmianom). Przykładów ze świata nauki jest wiele, a najczęściej chyba przytaczanymi są Oxford i Cambridge.

Po drugie, ważna jest oryginalność oferty (mniej istotne, czy będzie ona o profilu zawodowym, czy akademickim) i trafianie w społeczne zapotrzebowanie i oczekiwania. Idea life-long learning daje możliwość rozwijania studiów podyplomowych, różnego rodzaju kursów, także dla osób starszych. Tradycyjne kierunki akademickie, jak filozofia czy teologia, mogą utrzymać się jedynie dzięki jakości kształcenia lub/i uatrakcyjniania programów.

Po trzecie, system szkolnictwa wyższego w Polsce jest zbyt rozbudowany, nieadekwatnie do potrzeb (por. Antonowicz i Gorlewski 2011). Konieczne będą kolejne likwidacje, tworzenie grup lub wręcz fuzji instytucji edukacyjnych w poszczególnych regionach. Wtedy konkurowanie o ograniczone zasoby (czesne studentów i dotacje na badania) stanie się w pewnym sensie latwiejsze, ponieważ powstanie jeden większy, bardziej konkurencyjny (pod względem oferty i siły kadrowej) i wiarygodny (pod względem marki) podmiot. W Polsce dotychczas konsolidowały się podmioty prywatne. Przykładem takiego udanego połączenia jest fuzja Dolnośląskiej Wyższej Szkoły Służb Publicznych „Asesor” z Dolnośląską Szkołą Wyższą. Ta druga ma znaną markę i jest silniejszym podmiotem (Jastrzębska 2015). W sektorze publicznym fuzje nie są oparte wyłącznie na rachunku ekonomicznym, ale istotne są także silniejsza struktura zarządzania i bardziej elastyczne możliwości wykorzystania posiadanych zasobów. Przykładem takiego wzmocnienia było włączenie 10 lat temu do struktur Uniwersytetu Mikołaja Kopernika Akademii Medycznej w Bydgoszczy, która funkcjonuje w jego ramach jako Collegium Medicum. Wiele fuzji miało miejsce kilka lat temu w Szwecji, Finlandii i Danii, a ich głównym celem było dokonanie oszczędności w wydatkach publicznych i większa konkurencyjność oferty (Pinheiro, Geschwind i Aarrevaara 2013). Decydenci bardziej liczą się z silniejszymi graczami, co udowadniał w swoim tekście Ole-Jacob Skodvin (2014).

Po czwarte, wydaje się sensowne, by inwestować w młodych, dawać im szanse wyjazdów na stypendia i nawiązywania kontaktów ze światową nauką. Ich współpraca może w przyszłości przyczynić się do umiędzynarodowienia dorobku polskiej nauki. To nie jest dyskryminacja bardziej doświadczonych badaczy, tylko zwykła kalkulacja, że młody pracownik naukowy, który wypłynie na szersze wody w wieku - powiedzmy - 40 lat przyniesie więcej społecznych korzyści, niż by to się stało 20 lat później w kontekście jego jednostkowej biografii. Jest to też zgodne 
z do niedawna prowadzoną polityką naukową (por. Makowski i Kościelniak 2011: 285-300). Przydałoby się też zapewnienie większej stabilności zawodowej tej grupie, ale w obliczu wielu istotniejszych problemów ten temat musi ustąpić, choć powoduje negatywne konsekwencje, jak rezygnacja z kariery naukowej młodych badaczy czy emigracja (a więc drenaż mózgów).

Po piąte, należy wspierać te dziedziny humanistyki, które przyczyniają się do badania i tworzenia naszego dziedzictwa narodowego (choć może bardziej adekwatne byłoby określenie: kulturowego). Z tym że nie chodzi tylko o jego konserwację. Wielu współczesnych komentatorów wskazuje na problem z kanonem kulturowym i jego dezintegrację, a w konsekwencji na utrudnioną komunikację międzypokoleniową. Treści do tej pory klasyczne nie są już intersubiektywnie komunikowalne (Pisera 2006: 539-550). Potrzeba namysłu nad nowymi zjawiskami kulturowymi i wielu projektów badawczych. Humaniści nie są zbędni na nowych uniwersytetach. Muszą jedynie wyjść ze swoich gabinetów i rozejrzeć się wokół, gdzie mogliby się najbardziej przydać.

Po szóste, musimy zdawać sobie sprawę, że niestety polska nauka ma charakter peryferyjny, a dobre zespoły badawcze preferują pracę z równie dobrymi zespołami badawczymi (por. Zarycki 2013: 67-88). Nie jest to jednak powód, by z takich prób współpracy całkowicie rezygnować. Wielkim atutem jest tu graniczne położenie naszego kraju - między dwoma wpływowymi gospodarkami i kulturami (Zachód vs. Wschód). Projekty badawcze dotyczące regionu, realizowane we współpracy krajów z Grupy Wyszehradzkiej, są potencjalne interesujące dla obu stron (tj. Wschodu i Zachodu), ponieważ jesteśmy dla nich partnerami, a dokładniej jednym zbiorowym partnerem - Europą Środkową.

Współczesne uniwersytety mają wiele wad i czekają je zmiany, a środowisko naukowe nie będzie w stanie im zapobiec, mimo wyrażanego niezadowolenia. Obwinianie kultury korporacyjnej i nowych standardów kierowania instytucjami jest problemem zastępczym. Brakuje poważnego namysłu, jak utrzymać dotychczasową pozycję uniwersytetów w społeczeństwie w obliczu coraz większych problemów państwa opiekuńczego (czy socjalnego - w zależności od wyznawanej ideologii), wpływu globalizacji i niekorzystnych procesów demograficznych. Jak przekonać społeczeństwo, że edukacja i badania naukowe są wartością samą w sobie? Oto tematy, w odniesieniu do których powinna wykuwać się nowa idea uniwersytetu.

\section{Literatura}

Amaral, A., Kogan, M., Gornitzka, A. (red.) (2007). Reform and change in higher education. Analysing policy implementations. Dordrecht: Springer.

Antonowicz, D., Gorlewski, B. (2011). Demograficzne tsunami. Warszawa: Instytut Sokratesa.

Antonowicz, D., Jongbloed, B. (2015). Jaki ustrój uniwersytetu? Reformy szkolnictwa wyższego w Holandii, Portugalii i Austrii: wnioski dla Polski. Warszawa: Ernst \& Young. 
Banerski, G., Gryzik, A., Matusiak, K.B., Mażewska, M., Stawasz, E. (2009). Przedsiębiorczość akademicka. Raport z badania. Warszawa: PARP.

Buranen, L., Ray, A.M. (red.) (1999). Perspectives on plagiarism and intellectual property in a postmodern world. New York: University Press.

Cichorzewska, M. (2014). Tutoring w kształceniu akademickim. Edukacja - Technika - Informatyka. 5: 221-228.

Clark, B. (1998). Creating entrepreneurial universities: organisational pathways of transition. Oxford: Pergamon Press.

Coyle, D. (2012). Kod talentu. Jak zostać geniuszem. Warszawa: Wyd. Szachowe Penelopa.

Eurostat (2015). Education and training. http://ec.europa.eu/eurostat/web/education-and-training/data/main-tables [5.11.2015].

Florida, R. (2010). Narodziny klasy kreatywnej. Warszawa: NCK.

Fryzeł, B. (2005). Kultura korporacyjna. Poglądy, teorie, zarządzanie. Kraków: Wyd. Uniwersytetu Jagiellońskiego.

Goćkowski, J., Kisiel, P. (red.) (1994). Patologia i terapia życia naukowego. Kraków: Universitas.

Heller, M. (2009). Jak być uczonym. Kraków: Znak.

Intencje i skutki reformy szkolnictwa wyższego - dyskusja redakcyjna (2012). Kultura i Społeczeństwo. 1: 3-36.

Jastrzębska, L. (2015). Na kłopoty - konsolidacja. http://www.perspektywy.pl/portal/index. php?option=com_content\&view=article\&id $=982$ :na-klopoty-konsolidacja\&catid $=114 \&$ Item $\mathrm{id}=248[5 \cdot 11.2015]$.

Karwat, A. (oprac.) (2005). Czy twórczość jest obowiązkiem naukowca? Sprawy Nauki. Biuletyn MNiSzW. http://www.sprawynauki.waw.pl/?section=article\&art_id=1895 [4.11.2015].

Kiełb-Starczewska, E. (2012). Nauczyciel akademicki wobec zadań naukowych i dydaktycznych a udział mass mediów w jego pracy wychowawczej z młodzieżą studencką. http://edunet. amu.edu.pl/mae2012/43_Starczewska_2012.pdf [25.01.2016].

Kodeks etyki pracownika naukowego (2012). Załącznik do uchwały nr 10/2012 Zgromadzenia Ogólnego PAN z 13.12.2012 r.

Kościelniak, C., Makowski, J. (red.) (2011). Wolność, równość, uniwersytet. Warszawa: Instytut Obywatelski.

Kulczycki, E. (2015). Skazani na punktozę. http://ekulczycki.pl/warsztat_badacza/skazani-na-punktoze/ [15.10.2015].

Kwiek, M. (2010). Finansowanie szkolnictwa wyższego w Polsce a transformacje finansowania publicznego szkolnictwa wyższego w Europie, CPP RPS. 16. http://www.cpp.amu.edu.pl/ pdf/CPP_RPS_vol.16_Kwiek.pdf[25.01.2016].

Kwiek, M. (2015a). The European research elite: a cross-national study of higly productive academics in 11 countries. Higher Education. 9910. http://link.springer.com/article/10.1007/ s10734-015-9910-x/fulltext.html [25.01.2016].

Kwiek, M. (2015b). The University and the state in Europe. The uncertain future of the traditional social contract. W: R. Barnett, M. Peters (red.). The global university (t. 2: 2-21). New York: Peter Lang. http://www.cpp.amu.edu.pl/kwiek/pdf/Kwiek_for_Ron_Barnett_Final. pdf, [25.01.2016].

Kwiek, M. (2015c). Academic entrepreneurialism and changing governance at universities. Evidence from empirical studies. W: M. Reihlen, J. Frost, F. Hattke (red.). Multi-level gover- 
nance of universities: The role of strategies, structures and controls. Dordrecht: Springer. http://www.cpp.amu.edu.pl/kwiek/pdf/Kwiek_Entrepreneurialism_Spriner_2015.pdf [25.01.2016].

Labouvie-Vief, G., Blanchard-Fields, F. (1982). Cognitive ageing \& psychological growth. Ageing \& Society. 2(2): 183-209.

Martino, J.P. (1992). Science Funding. Politics and Porkbarrel. New Brunswick - London: Transaction Publishers.

North, D.C. (1990). Institutions, institutional change and economic performance. Cambridge: Cambridge University Press.

OECD (2008). Universities, innovation and entrepreneurship. Criteria and examples of good practice. http://www.oecd.org/cfe/leed/43201452.pdf [4.11.2015].

Pacholski, L. (2015). Wystąpienie podczas debaty „Polskiej nauki życie na niby. Jak z tego wyjść?”. Wrocław 10.06.2015. https://wszystkoconajwazniejsze.pl/naukapolska-debata-wewroclawiu-zycie-na-niby-polskiej-nauki-jak-z-tego-wyjsc/ [4.11.2015].

Pinheiro, R., Geschwind, L., Aarrevaara, T. (2013). Mergers in higher education and beyond: stocktaking and assessment. https://www.diva-portal.org/smash/get/diva2:815407/FULLTEXT01.pdf [4.11.2015].

Pisera, J. (2006). Kanon czy jego dezintegracja? Oceny, diagnozy, polemiki, kontrowersje. Acta Universitatis Lodziensis. Folia Litteraria Polonica. 8: 539-550.

Popławski, W., Markowski, M., Forkiewicz, M. (2013). Przedsiębiorczość polskich szkół wyższych. Diagnoza, uwarunkowania, perspektywy. Raport z badań. Toruń: WSB.

Skodvin, O.-J. (2014). Merger as an instrument to achieve quality in HE? Rhethoric or reality? Paper presented at EAIR $36^{\text {th }}$ Annual Forum in Essen, Germany.

Szlachta, B. (2013). O problematyczności (niektórych) liberalnych prób ustanawiania uniwersalnie ważnych „zasad racjonalności współdziałań”. W: J. Górniak, J. Hausner, S. Mazur (red.). Zarządzanie Publiczne. 2-3(24-25): 44-52.

Wieczorek, J. (2003). Mobbing uczelniany. Obywatel. 6(14): 11-13.

Wieczorek, J. (2010). Etyka i patologie polskiego środowiska akademickiego. Kraków: Niezależne Forum Akademickie.

Wroński, M. (2010). Profesorskie plagiaty. Forum Akademickie. 6. https://forumakademickie. $\mathrm{pl} / \mathrm{fa} / 2010 /$ o6/profesorskie-plagiaty/ [4.11.2015].

Wylęgała, A. (2014). Przesiedlenia a pamięć. Studium (nie)pamięci społecznej na przykładzie ukraińskiej Galicji i polskich „ziem odzyskanych”. Toruń: UMK.

Zabel, M., Rafajłowicz, E., Dahlig-Turek, E., Hanke, W., Mach, B., Brzeziński, P. (2014). Punktoza, czyli wskaźniki bibliometryczne stosowane przez KEJN w ocenie parametrycznej jednostek naukowych. Forum Akademickie. 9. https://forumakademickie.pl/fa/2014/o9/punkto$\mathrm{za} /[4.11 .2015]$.

Zając, Cz. (2012). Kulturowe i personalne problemy zarządzania zasobami ludzkimi w międzynarodowych grupach kapitałowych w świetle badań empirycznych. Human Resource Management. 6: 71-87.

Zarycki, T. (2012). Polskie nauki społeczne w świetle hipotezy peryferyjnej dualności. Zagadnienia Naukoznawstwa. 195 (1): 67-88.

Znaniecki, F. (1940). The social roles of the men of knowledge. New York: Columbia University Press. Żylicz, M. (2006). Ocena parametryczna dzisiaj i jutro. Forum Akademickie. 6. http://www.forumakad.pl/archiwum/2006/06/22_ocena_parametryczna.html [4.11.2015]. 


\section{The university without idea}

ABSTRACT. Achievements of Congress of Academic Culture that took place in Cracow in 2014 were clarified in work titled The idea of the university. Reactivation. This book is a critique of contemporary trends in higher education and suggests restitution of the nineteenth-century model of university. In the article author attempted to contest the critical arguments outlined in the opening remarks of Piotr Sztompka. In the second part, author wanted to explain why a return to the idea of Humboldt is a pipe dream. Finally, in third section one presented these elements of institutional strategy, that could work in Polish context, if only reforms have been performed now.

KEYWORDS: university, change, academic culture, academic labour

CYTOWANIE: Smużewska, M. (2015). Uniwersytet bez idei. Nauka i Szkolnictwo Wyższe. 1(45): 309-324. DOI: 10.14746/nsw.2015.1.12. 